\title{
EXPERIENTIAL MARKETING WISATA TAMAN KOTA SURABAYA
}

\author{
Citra Anggraini Tresyanto \\ Program Studi Manajemen \\ Fakultas Ekonomi Universitas Katolik Darma Cendika \\ Jalan Dr. Ir. H. Soekarno 201, Surabaya \\ Bruno Hami \\ Program Studi Manajemen \\ Fakultas Ekonomi Universitas Katolik Darma Cendika \\ Jalan Dr. Ir. H. Soekarno 201, Surabaya
}

\begin{abstract}
The public need big cities nowadays are very complex. No exception to the needs of the people of Surabaya. One of the new needs of urban society is traveled. Traveled synonymous with waste of money. Not at this time, traveled enough to spend time with visiting the city park. Surabaya has a lot of city parks that can be utilized by the community. A total of 27 active city park owned by Surabaya. But unfortunately some of them, can be utilized by the community. Apart from that, the city park form a new lifestyle and needs in the community that traveled in a city park. Travelling in the city park provides an exciting experience. An interesting experience can be formed through a component in experiential marketing, namely sense, feel, think, act and relate that will describe a new experience as a result of a particular stimulus. Through experiential marketing also, the city government can find out what people felt after visiting the city and what is needed by the community. Proved that the city parks are built and design well, according to the needs and expectations of the community. This is clearly evident from the many community activities in the city park on the weekends.
\end{abstract}

\begin{abstract}
ABSTRAK
Kebutuhan masyarakat kota besar dewasa ini sangatlah kompleks. Tak terkecuali dengan kebutuhan masyarakat kota Surabaya. Salah satu kebutuhan baru masyarakat kota adalah berwisata. Berwisata identik dengan menghamburkan uang. Tidak dengan saat ini, berwisata cukuplah menghabiskan waktu dengan mengunjungi taman kota. Surabaya memiliki banyak taman kota yang dapat dimanfaatkan oleh masyarakat. Total 27 taman kota aktif dimiliki oleh Surabaya. Namun sayang beberapa diantaranya kurang dapat dimanfaatkan dengan baik oleh masyarakat. Terlepas dari hal itu, adanya taman kota membentuk suatu gaya hidup dan kebutuhan baru di masyarakat yaitu berwisata di taman kota. Berwisata di taman kota tersebut memberikan suatu pengalaman yang menarik. Pengalaman yang menarik ini dapat dibentuk melalui komponen dalam experiential marketing,
\end{abstract}


yaitu sense, feel, think, act dan relate yang akan menggambarkan suatu pengalaman baru sebagai akibat dari suatu stimulus tertentu. Melalui experiential marketing pula, pemerintah kota dapat mengetahui apa yang dirasakan masyarakat setelah mengunjungi taman kota dan apa yang dibutuhkan oleh masyarakat. Terbukti bahwa taman kota yang dibangun dan didesain dengan baik, sesuai dengan kebutuhan serta harapan dari masyarakat. Hal ini jelas terlihat dari banyaknya aktivitas masyarakat di taman kota saat akhir pekan.

Keywords: experiential marketing, the city park.

\section{PENDAHULUAN}

Surabaya merupakan kota terbesar kedua di Indonesia, setelah Jakarta. Tak berbeda jauh dengan Jakarta, Surabaya juga mampu menarik turis domestik atau mancanegara untuk berwisata ataupun berbisnis. Sebagai kota besar, kebutuhan dan gaya hidup masyarakat kota Surabaya sangat kompleks. Salah satu contohnya adalah kebutuhan untuk berwisata. Jika beberapa waktu yang lalu wisata bukan menjadi suatu kebutuhan, maka tidak dengan sekarang. Berwisata menjadi sebuah kebutuhan yang cukup penting.

Pandangan masyarakat terhadap wisata juga telah berubah. Berwisata tidak hanya harus pergi ke luar kota atau pusat perbelanjaan seperti mall dan menghabiskan dana yang besar. Kini, masyarakat bisa menikmati sederetan tempat wisata yang ditawarkan oleh Kota Surabaya tanpa mengeluarkan dana yang besar. Salah satu tempat wisata favorit masyarakat Surabaya untuk melepas penat atau sekedar menghirup udara segar dengan rimbunan pohon dan tanaman rindang adalah dengan menghabiskan waktu di taman kota yang dimiliki oleh Surabaya. Sesuai harapan walikota Surabaya, Tri Rismaharini, dengan membangun banyak taman kota di Surabaya, maka selain untuk keindahan tata kota sendi- ri, juga agar warga masyarakat dapat memiliki tempat untuk melakukan aktivitas positif seperti olah raga sekaligus menikmati suasana pohon dan tanaman yang rindang, bermain bersama anak-anak dan sebagainya.

Terbukti bahwa hampir di semua taman kota yang ada di Surabaya di setiap akhir pekan selalu dipadati oleh warga masyarakat. Banyak aktivitas yang mereka lakukan di sana, entah hanya sekedar menghabiskan waktu malam minggu ataupun bermain bersama anak-anak dengan menikmati jajanan yang ada di sekitar taman kota. Aktivitas positif tersebut tidak hanya berlangsung pada malam hari, namun juga pada pagi hari. Aktivitas pagi hari di taman kota adalah berolah raga ringan seperti jogging, bersepeda, senam, terapi batu jalan setapak, dan lain sebagainya.

Meski memiliki segudang manfaat bagi warga masyarakat, taman kota merupakan fasilitas umum yang seringkali mendapat keluhan dari warga sendiri melalui apa yang mereka rasakan selama menikmati taman kota tersebut. Keluhan tersebut bukan tanpa alasan, melainkan warga sendiri ingin memiliki fasilitas umum yang baik dan dapat dibanggakan. Wisata taman kota ini akan memberikan pengalaman atau experience yang berbeda bagi masya- 
rakat yang menikmati. Hal ini menuntut wisata taman kota harus didukung oleh berbagai fasilitas yang memadai untuk berbagai kebutuhan aktivitas masyarakat.

\section{TINJAUAN PUSTAKA Konsep Taman Kota}

Secara umum terdapat perbedaan antara taman sebagai landscape dan taman sebagai garden, yaitu bahwa taman (landscape) elemen tamannya lebih banyak didominasi oleh elemen alami, sedangkan (garden) elemennya lebih didominasi oleh elemen buatan manusia (artificial) dan dalam luas yang lebih terbatas (Suharto, 1994: 5). Taman sendiri jika diterjemahkan dari bahasa Ibrani, yaitu 'Gan' berarti melindungi atau mempertahankan lahan yang ada dalam suatu lingkungan berpagar, 'Oden' berarti kesenangan, kegembiraan, dan kenyamanan. Secara lengkap dapat diartikan taman adalah sebidang lahan berpagar yang digunakan untuk mendapatkan kesenangan, kegembiraan, dan kenyamanan (Laurie, 1986: 9).

Taman kota berdasarkan rancangannya terbagi atas:

1. Taman Alami (Natural)

Taman alami atau natural adalah suatu taman yang dirancang untuk memberikan kesan alami atau menyatu dengan alam. Taman alami sudah terbentuk sebelumnya, namun dalam penataannya disesuaikan dengan kondisi lahan kota, misalnya hutan kota, taman pengarah jalan, taman alami yang tumbuh dalam kota, dan sebagainya.

2. Taman Buatan (Artificial)

Taman buatan atau artificial merupakan sebuah taman yang elemenelemennya lebih banyak didominasi dengan elemen buatan manusia
(Suharto, 1994: 9). Taman artificial dirancang untuk menyeimbangkan kondisi kota dan taman kota, antara lain bermanfaat untuk mengendalikan suhu, panas sinar matahari, pengendali angin, memperbaiki kualitas udara, untuk sarana bermain, rekreasi, memberikan kesenangan, kegembiraan, kenyamanan, sebagai pembatas fisik, pengontrol pandangan, dan lain sebagainya.

Berdasarkan aktivitasnya taman kota dibagi menjadi 3 (tiga) macam, yaitu:

1. Taman untuk rekreasi aktif Jenis taman yang di dalamnya dibangun suatu kegiatan pemakai taman, sehingga pemakai taman secara aktif menggunakan fasilitas di dalamnya, sekaligus memperoleh kesenangan, kesegaran, dan kebugaran, misalnya taman olah raga, aerobic, fitness, camping ground, taman bermain anak, taman pramuka, taman jalur jalan, kebun binatang, danau, pemancingan tamantaman kota dan sebagainya.

2. Taman untuk rekreasi pasif

Jenis taman yang dibentuk agar dapat dinikmati keindahan dan kerindangannya, tanpa mengadakan aktivitas dan kegiatan apapun. Misalnya waduk, hutan buatan, penghijauan tepi kali, jalur hijau, lapangan terbang, dan lainnya.

3. Taman untuk rekreasi aktif dan pasif

Jenis taman yang bisa dinikmati keindahan sekaligus ada fungsi lain dan dapat digunakan untuk mengadakan aktivitas, misalnya taman lingkungan. Taman lingkungan atau community park adalah suatu taman yang dibuat dan merupakan bagian dari suatu pemukiman, selain rumah ibadah, pasar, sekolah, dan lainlainnya (Suharto, 1999: 12-13). 


\section{Pengertian dan Manfaat dari Experiential Marketing}

Experiential Marketing berasal dari dua kata yaitu Experiential dan Marketing. Kata experiential sendiri berasal dari kata experience yang berarti sebuah pengalaman. Menurut Schmitt (1999) experiences are private events that occur in response to some stimulation (e.g. as provided by marketing efforts before and after purchase) yang berarti pengalaman merupakan peristiwa-peristiwa pribadi yang terjadi dikarenakan adanya stimulus tertentu. Pine II and Gilmore (1999) berpendapat bahwa experience are event that engage individuals in a personal way yang berarti pengalaman adalah suatu kejadian yang terjadi dan mengikat pada setiap individu secara personal.

Menurut Berman and Evans (2007) marketing is the anticipation, management and satisfaction of demand through the exchange process, artinya marketing adalah suatu aktivitas untuk melakukan antisipasi, pengelolaan dan pencapaian kepuasan konsumen melalui proses pertukaran. Sedangkan menurut Stanton (2003) pemasaran (marketing) adalah suatu sistem keseluruhan dari kegiatankegiatan bisnis yang ditujukan untuk merencanakan, menentukan harga, mempromosikan, dan mendistribusikan barang dan jasa yang memuaskan kebutuhan, baik kepada pembeli yang ada maupun pembeli yang potensial.

Untuk memberikan penjelasan yang lebih detil mengenai experiential marketing, Schmitt (1999) memberikan suatu framework yang menjelaskan komponen apa saja yang ada di dalam experiential marketing. Experiential Modules menurut Schmitt (1999) antara lain terdiri dari:
1. Sense

Sense adalah aspek-aspek yang berwujud dan dapat dirasakan dari suatu produk yang dapat ditangkap oleh kelima indera manusia meliputi pandangan, suara, bau, rasa, dan sentuhan. Sense ini bagi konsumen berfungsi untuk mendiferensiasikan suatu produk dari produk yang lain, untuk memotivasi pembeli untuk bertindak, dan untuk membentuk value pada produk atau jasa dalam benak pembeli.

2. Feel

Perasaan berhubungan dengan perasaan yang paling dalam dan emosi pelanggan. Iklan yang bersifat feel good biasanya digunakan untuk membuat hubungan dengan pelanggan, menghubungkan pengalaman emosional mereka dengan produk atau jasa, dan menantang pelanggan untuk bereaksi terhadap pesan feel campaign yang sering digunakan untuk membangun emosi pelanggan secara perlahan.

3. Think

Perusahaan berusaha untuk menantang konsumen, dengan cara memberikan problem-solving experiences, dan mendorong pelanggan untuk berinteraksi secara kognitif dan atau secara kreatif dengan perusahaan atau produk. Iklan pikiran biasanya lebih bersifat tradisional, menggunakan lebih banyak informasi tekstual, dan memberikan pertanyaan-pertanyaan yang tak terjawabkan. Menurut Schmitt (1999) cara yang baik membuat think campaign berhasil adalah: (1) menciptakan sebuah kejutan yang dihadirkan baik dalam bentuk visual, verbal ataupun konseptual; (2) berusaha untuk memikat pelanggan; dan (3) memberikan sedikit provokasi. 
4. Act

Tindakan yang berhubungan dengan keseluruhan individu (pikiran dan tubuh) untuk meningkatkan hidup dan gaya hidupnya. Pesan-pesan yang memotivasi, menginspirasi dan bersifat spontan dapat menyebabkan pelanggan untuk berbuat hal-hal dengan cara yang berbeda, mencoba dengan cara yang baru merubah hidup mereka lebih baik.

5. Relate

Relate menghubungkan pelanggan secara individu dengan masyarakat, atau budaya. Relate menjadi daya tarik keinginan yang paling dalam bagi pelanggan untuk pembentukan self-improvement, status socio-economic, dan image. Relate campaign ditujukan kepada sekelompok orang yang merupakan target pelanggan di mana seorang pelanggan dapat berinteraksi, berhubungan, dan berbagi kesenangan yang sama.

\section{METODE PENELITIAN}

Jenis penelitian ini adalah kualitatif deskriptif. Penelitian ini bermaksud memahami respon dan harapan masyarakat pada fasilitas yang dibangun oleh pemerintah kota yaitu taman kota di Surabaya.

Dengan menggunakan teknik pengumpulan data observasi dan wawancara dari para pengunjung akan dapat diketahui secara langsung bagaimana respon dan pengalaman apa yang mereka rasakan pada saat melakukan wisata taman kota. Informan utama dalam penelitian ini adalah para pengunjung.

\section{PEMBAHASAN}

Total keseluruhan kota Surabaya memiliki 27 taman aktif yang tersebar di seluruh wilayah kota Surabaya. Daftar taman tersebut per-wilayah nampak seperti terlihat pada Tabel 1.

Tabel 1

Daftar Taman di Kota Surabaya

\begin{tabular}{|c|c|}
\hline Surabaya Barat & Surabaya Utara \\
\hline $\begin{array}{l}\text { - } \quad \text { Taman Bungkul } \\
\text { - Taman Keputran } \\
\text { - Taman Persahabatan } 2 \\
\text { - Taman Apsari } \\
\text { - Taman Buah-buahan } \\
\text { - Taman Ekspresi } \\
\text { - Taman Kombes Pol. M. Duryat } \\
\text { - Taman Pakal } \\
\end{array}$ & $\begin{array}{ll} & \text { Taman Jayengrono } \\
\text { - } & \text { Taman Krembangan Timur } \\
\text { - } & \text { Taman Kalongan } \\
\text { - } & \text { Taman Barunawati } \\
\text { - } & \text { Taman Nambangan }\end{array}$ \\
\hline Surabaya Timur & Surabaya Selatan \\
\hline $\begin{array}{ll}\text { - } & \text { Taman Mundu } \\
\text { - } & \text { Taman Teratai } \\
\text { - } & \text { Taman Paliatif } \\
\text { - } & \text { Taman Lansia } \\
\text { - } & \text { Taman Flora Bratang } \\
\text { - } & \text { Taman Flora Wonorejo } \\
\text { - } & \text { Taman Surya } \\
\text { - } & \text { Taman Prestasi } \\
\text { - } & \text { Taman Karimun Jawa } \\
\text { - } & \text { Taman Persahabatan } 1 \\
\text { - } & \text { Taman Kunang-kunang } \\
\end{array}$ & $\begin{array}{ll}\text { - } & \text { Taman Ronggolawe } \\
\text { - } & \text { Taman Pelangi } \\
\text { - } & \text { Taman Wira Surya Agung } \\
\text { - } & \text { Taman Jagir }\end{array}$ \\
\hline
\end{tabular}


Dengan adanya taman-taman aktif tersebut kini warga masyarakat memiliki aktivitas baru yaitu diantaranya olah raga ringan seperti jogging, senam dan lain-lain. Sementara untuk anak-anak juga dapat bermain dengan fasilitas permainan yang telah disediakan atau melakukan aktivitas fisik yang menyehatkan. Meskipun taman-taman yang ada terletak di tengah kota, namun cukup memberikan udara yang bersih dan segar berkat adanya tanaman-tanaman yang diatur sedemikian rupa. Berikut adalah hasil pengolahan data dengan pendekatan experiential marketing melalui observasi, pengamatan pada taman kota dan pengunjung serta dokumen yang diperoleh.

Tabel 2

Hasil Pengolahan Data dengan Experiential Marketing

\begin{tabular}{|l|l|l|}
\hline No & Faktor Experiential Marketing & \multicolumn{1}{|c|}{ Hasil Pengolahan Data } \\
\hline 1 & $\begin{array}{l}\text { Variabel Sense } \\
\text { Merupakan aspek berwujud } \\
\text { yang dapat dirasakan oleh } \\
\text { panca indera manusia. }\end{array}$ & $\begin{array}{l}\text { Suasana pemandangan di sekitar } \\
\text { tempat wisata taman kota cukup } \\
\text { baik dan menyenangkan. } \\
\text { Makanan yang dijual merupakan } \\
\text { favorit sebagian besar orang, na- } \\
\text { mun memang diakui oleh sebagi- } \\
\text { an besar masyarakat bahwa ke- } \\
\text { bersihan dan kesehatan makanan } \\
\text { tidak terjamin. } \\
\text { Suara-suara bising (kendaraan) } \\
\text { tidak terlalu mengganggu kegiat- } \\
\text { an refreshing, karena masyarakat } \\
\text { menyadari taman kota yang me- } \\
\text { reka kunjungi berada di tengah } \\
\text { kota. } \\
\text { Bau sampah/selokan air terka- } \\
\text { dang cukup mengganggu. Di } \\
\text { samping masih banyaknya } \\
\text { pedagang yang tidak menjaga } \\
\text { kebersihan dan masyarakat yang } \\
\text { membuang sampah sembarangan } \\
\text { (meski sudah disediakan tempat } \\
\text { sampah di beberapa sudut ta- } \\
\text { man). }\end{array}$ \\
\hline
\end{tabular}




\begin{tabular}{|l|l|l|}
\hline & & $\begin{array}{l}\text { Panasnya suhu di Surabaya men- } \\
\text { jadikan taman kota tidak tepat } \\
\text { dikunjungi pada siang hari. } \\
\text { Antara pukul 11.00-14.00 WIB } \\
\text { taman kota terlihat sepi } \\
\text { pengunjung. }\end{array}$ \\
\hline 2 & $\begin{array}{l}\text { Variabel Feel } \\
\text { Menggugah perasaan pengun- } \\
\text { jung saat berwisata di taman } \\
\text { kota. }\end{array}$ & $\begin{array}{l}\text { Suasana refresh/segar-nya tempat } \\
\text { Wisata taman kota memberikan } \\
\text { perasaan yang menggembirakan. } \\
\text { Memberikan inspirasi. }\end{array}$ \\
\hline 4 & $\begin{array}{l}\text { Variabel Act } \\
\text { Merubah suatu tindakan dari } \\
\text { kebiasaan atau rutinitas masya- } \\
\text { rakat. }\end{array}$ & $\begin{array}{l}\text { Tempat wisata taman kota } \\
\text { memberikan inspirasi/ide baru } \\
\text { bagi para pengunjung. } \\
\text { taman kota di Surabaya membuat } \\
\text { masyarakat Surabaya memiliki } \\
\text { rutinitas rekreasi yang baru di } \\
\text { setiap akhir pekan. }\end{array}$ \\
\hline 5 & $\begin{array}{l}\text { Variabel Relate } \\
\text { Membangun hubungan masya- } \\
\text { rakat dengan sekitarnya. }\end{array}$ & $\begin{array}{l}\text { Mengunjungi tempat wisata ter- } \\
\text { sebut membuat kecintaan dan } \\
\text { kebanggaan terhadap kota Sura- } \\
\text { baya semakin meningkat. }\end{array}$ \\
\hline
\end{tabular}

Taman pertama yang dibangun dan difungsikan lebih maksimal oleh Pemerintah Kota Surabaya adalah Taman Bungkul yang terletak di Jalan Raya Darmo. Taman Bungkul ini memiliki luas $\pm 900 \mathrm{~m}^{2}$ dengan dilengkapi konsep sport, entertainment dan education. Sejak diresmikan pada tanggal 21 Maret 2007, Taman Bungkul mengalami perbaikan dan perkembangan yang cukup pesat. Salah satunya yaitu kelengkapan sarana dan prasarana penunjang, seperti skateboard track dan BMX track, jogging track, plaza atau panggung yang disediakan untuk live performan- ce berbagai jenis kegiatan, zona akses Wi-Fi gratis, area green park dengan kolam air mancur, taman bermain anak-anak hingga pujasera dengan bermacam menu yang ditawarkan.

Taman Bungkul merupakan taman kota yang paling populer di Surabaya, hal ini tidak lepas dari peran pemerintah kota yang memaksimalkan fungsi taman kota itu sendiri. Berkat kerja keras dari pemerintah kota sendiri, Taman Bungkul meraih penghargaan The 2013 Asian Townscape Award dari Perserikatan BangsaBangsa sebagai taman terbaik se-Asia pada tahun 2013. 


\section{KESIMPULAN}

Jika dilihat lebih jauh, beberapa taman kota yang ada masih perlu banyak perhatian dari pemerintah. Seperti contohnya Taman Barunawati yang tampaknya kurang tertata dengan baik dan juga sangat minim minat masyarakat karena letaknya yang tidak strategis. Dari segi fasilitas dan perawatan masih belum tersentuh oleh pemerintah seperti pada taman kota Jagir. Hal ini bisa dikarenakan letak taman kota yang kurang strategis dan ketidaktahuan masyarakat akan fungsi dari taman kota yang ada.

\section{SARAN}

Taman kota bukanlah murni milik pemerintah kota, hanya saja pengelolaannya yang menjadi tanggung jawab pemerintah kota. Taman kota merupakan milik masyarakat itu sendiri, maka sudah semestinya masyarakat ikut ambil bagian pada pengelolaannya. Melalui kegiatan-kegiatan penghijauan yang digagas oleh pemerintah, masyarakat bisa ikut ambil bagian di dalamnya. Tidak cukup sampai disitu, pemerintah juga dapat memberikan wadah bagi perusahaan swasta untuk pelaksanaan program CSR (corporate social responsibility) pada pembangunan taman kota. Dengan begitu masyarakat akan ikut menjaga, merawat dan melestarikan. Di samping itu masyarakat akan mempunyai rasa memiliki serta kebanggaan sebagai warga masyarakat yang ikut aktif dalam membangun keindahan kota Surabaya.

\section{DAFTAR KEPUSTAKAAN}

Berman, Barry and Joel R. Evans, 2007, Retail Management, Prentice Hall, New Yersey.
Laurie, Michael, 1986, Arsitektur Pertamanan, Intermatra, Bandung.

Miles dan A. Michael Huberman, 1992, Analisis Data Kualitatif, Universitas Indonesia, Jakarta.

Pine II, B.J. and J.H. Gilmore, 1999, The Experience Economy: Work is Theater \& every Business a Stage, Harvard Business Press, United States of America.

Schmitt, B., 1999, Experiential Marketing: How to Get Customers to Sense, Feel, Think, Act, Relate to Your Company and Brands, The Free Press, New York.

Soegiyono, M., 2007, Metodologi Penelitian Kuantitatif, Kualitatif, $R \& D, C V$. Alfabeta, Bandung.

Stanton, William J., 2003, Prinsip Pemasaran, Jilid Satu, Edisi Kesepuluh, Alih Bahasa: Sadu Sundaru, Erlangga, Jakarta.

Suharto, 1994, Dasar-Dasar Pertamanan, Media Wiyata, Semarang.

https://wisataman.wordpress.com/daftar-taman-kota-surabaya/, diakses pada tanggal 23 Juni 2016 